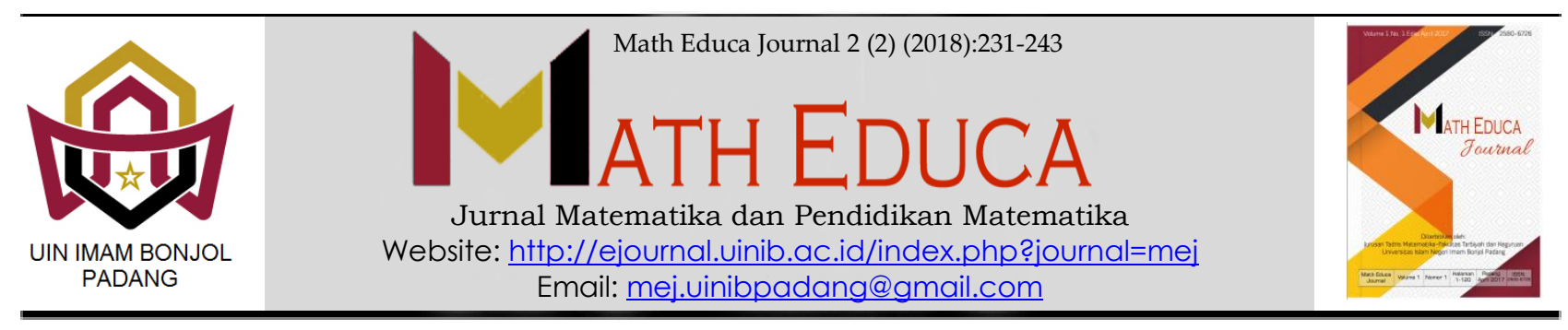

\title{
Identifikasi Kesalahan dan Miskonsepsi Mahasiswa Calon Guru Matematika Pada Topik SPLDV
}

\author{
Juli Afriadi \\ Tadris Matematika, Fakulta Tarbiyah dan Keguruan UIN IB Padang, Indonesia \\ juliafrie7adi@gmail.com
}

Received: August 2018; Accepted: September 2018; Published: Ocober 2018

\begin{abstract}
Abstrak
Penelitian ini bertujuan untuk mengidentifikasi kesalahan dan miskonsepsi mahasiswa calon guru matematika pada materi SPLDV.Penelitian ini menggunakan desain penelitian kualitatif. Data penelitian dikumpulkan dari 15 mahasiswa micro teaching semester VI UNP Padang, dengan menggunakan tes soal dan pedoman wawancara. Tes soal SPLDV yang disusun meliputi konsepSPLDV dengan solusi tak hingga dan SPLDV dengan tepat satu solusi. Hasil penelitian menunjukkan adanya sejumlah kesalahan dan miskonsepsi dari materi tersebut.Kesalahan mahasiswa yang teridentikfikasi yaitu kesalahan konsep, yaitu kesalahan yang yang dilakukan mahasiswa karena tidak memahami konsep SPLDV dengan baik. Kesalahan strategi, yaitu kesalahan yang terjadi karena mahasiswa memilih cara mengerjakan yang tidak tepat. Kesalahan hitung, yaitu kesalahan dalam melakukan operasi matematika.Kesalahan sistematik, yaitu kesalahan yang berkenaan dengan pemilihan yang salah atas teknik ekstrapolasi.Hasil wawancara menunjukkan penyebab miskonsepsi yang dialami oleh mahasiswa yaitu ketidak tahuan, kesalahan bahasa, tayangan film, kemampuan berfikir, latar belakang keluarga, konsepsi parallel, dan kesalahan konsepsi awal mahasiswa.
\end{abstract}

Kata Kunci: Miskonsepsi, SPLDV, Matematika

\section{Abstract}

This research aims to identify errors and misconceptions of prospective mathematics teacher students in the SPLDV material. This study uses a qualitative research design. Research data was collected from 15 micro teaching students in the sixth semester of UNP Padang, using test questions and interview guidelines The SPLDV test questions prepared include the concept of SPLDV with infinite solutions and SPLDV with exactly one solution. The results of the study indicate that there are a number of errors and misconceptions of the material. Identified student errors are conceptual errors, namely mistakes made by students because they do not understand the SPLDV concept properly. Strategic error, which is an error that occurs because students choose the wrong way to do it. Calculate errors, namely errors in performing mathematical operations. Systematic error, which is an error regarding the wrong selection of extrapolation techniques. The interview results show the causes of misconceptions experienced by students, namely ignorance, language errors, film shows, thinking skills, family background, parallel conceptions, and initial student misconceptions.

Keywords: Misconception, SPLDV, Mathematics

\footnotetext{
${ }^{*}$ Corresponding author.

Peer review under responsibility UIN Imam Bonjol Padang.

(c) 2018 UIN Imam Bonjol Padang. All rights reserved.

p-ISSN: 2580-6726

e-ISSN: 2598-2133
} 


\section{PENDAHULUAN}

Matematika dapat mengembangkan pemikiran kritis, kreatif, sistematis, dan logis serta telah memberikan kontribusi dalam kehidupan sehari-hari mulai dari hal yang sederhana seperti perhitungan dasar (basic calculation) sampai hal yang kompleks dan abstrak seperti penerapan analisis numeric dalam bidang teknik dan sebagainya. Hali ini senada dengan pendapat Suherman, (2003) yang menyatakan bahwa tujuan pembelajaran matematika antara lain adalah agar siswa mampu menghadapi perubahan keadaan di dunia yang selalu berkembang, melalui latihan bertindak atas dasar pemikiran secara logis, rasional, kritis, cermat, jujur, dan efektif.

Kesumawati (2008) menyatakan bahwa landasan penting yang harus dimiliki oleh peserta didik dalam usahanya untuk berpikir menyelesaikan permasalahan matematika maupun permasalahan dalam kehidupan sehari-hari, adalah kemampuan dalam memahami konsep matematika. Pentingnya kemampuan pemahaman konsep matematika juga dijelaskan dalam prinsip pembelajaran matematika yang dinyatakan oleh National Counsil of Teaching Mathematics (NCTM) yaitu: "para peserta didik harus belajar matematika dengan pemahaman, secara aktif membangun pengetahuan baru dari pengalaman dan pengetahuan sebelumnya." Prinsip ini didasarkan pada ide bahwa belajar matematika dengan pemahaman adalah penting. Belajar matematika tidak hanya memerlukan keterampilan menghitung tetapi juga memerlukan kecakapan untuk berpikir dan beralasan secara matematis untuk menyelesaikan soal-soal baru dan mempelajari ide-ide baru yang akan dihadapi oleh peserta didik di masa yang akan dating (Van de Walle, 2006).

Pemahaman diartikan dari kata understanding (Sumarmo, 1987). Derajat pemahaman ditentukan oleh tingkat keterkaitan suatu gagasan, prosedur atau fakta matematika dipahami secara menyeluruh jika hal-hal tersebut membentuk jaringan dengan keterkaitan yang tinggi.Dan konsep diartikan sebagai ide abstrak yang dapat digunakan untuk menggolongkan sekumpulan objek (Depdiknas, 2003: 18).

Menurut Skemp (1976) pemahaman matematika dapat digolongkan berdasarkan kemampuan yang dimilikinya, yaitu pemahaman instrumental dan pemahaman relasional. Mahasiswa dikatakan mampu memahami secara instrumental jika ia mampu mengingat kembali hal-hal yang telah dikomunikasikan kepadanya, hal yang termasuk dalam tingkat ini adalah pengetahuan tentang fakta dasar, istilah, ataupun hal-hal yang bersifat rutin seperti perhitungan sederhana. Tingkat selanjutnya adalah pemahaman relasional.Dalam tingkatan ini mahasiswa sudah

\footnotetext{
*Corresponding author.

Peer review under responsibility UIN Imam Bonjol Padang.

(C) 2018 UIN Imam Bonjol Padang. All rights reserved. 
mampu menerapkan dengan tepat suatu ide matematika yang bersifat umum pada hal-hal yang khusus atau pada situasi baru. Menurut Duffin \& Simpson (2000) pemahaman konsep sebagai kemampuan siswa untuk: (1) menjelaskan konsep, dapat diartikan siswa mampu untuk mengungkapkan kembali apa yang telah dikomunikasikan kepadanya. (2) menggunakan konsep pada berbagai situasi yang berbeda. Dan (3) mengembangkan beberapa akibat dari adanya suatu konsep, dapat diartikan bahwa siswa paham terhadap suatu konsep akibatnya siswa mempunyai kemampuan untuk menyelesaikan setiap masalah dengan benar.

Matematika merupakan ilmu yang terstruktur sehingga kesalahan mempelajari konsep terdahulu akan berpengaruh terhadap pemahaman konsep berikutnya. Menurut Lerner (Mulyono, 1999:262) kesalahan umum yang dilakukan siswa dalam mengerjakan tugas matematika yaitu kurangnya pengetahuan tentang simbol, kurangnya pemahaman tentang nilai tempat, penggunaan proses yang keliru, kesalahan perhitungan, dan tulisan yang tidak dapat dibaca sehingga siswa melakukan kekeliruan karena tidak mampu lagi membaca tulisannya sendiri.

Beberapa keadaan dalam perkuliahan matematika dijumpai penguasaan konsep mahasiswa calon guru matematika masih rendah.Walaupun mahasiswa dapat mengingat fakta-fakta, proses-proses, prinsip-prinsip, dan rumus-rumus, mereka hanya memahami sedikit konsep-konsep dasar SPLDV.Pada umumnya mereka memiliki sedikit kemampuan untuk menghubungkan konsep yang mereka pelajari dari buku ajar maupun dengan lingkungannya.Kondisi demikian tentu saja sangat berbahaya mengingat mahasiswa calon guru ini akan melaksanakan Praktik Pengalaman Lapangan (PPL) mengajar di sekolah latihan pada semester berikutnya. Tidak bisa kita bayangkan bagaimana jadinya jika guru praktikan ini mengajar, namun yang diajarkan konsepnya ternyata salah (miskonsepsi) atau berkebalikan dengan konsep ilmuan. Miskonsepsi berbahaya karena memberikan murid-murid pemikiran /rasa (sense) yang salah dalam mengetahui sehingga membatasi usaha mental yang mereka investasikan dalam belajar, dan terjadi interferensi antara konsep yang telah dipelajari (salah) dengan yang sedang dipelajari (benar). Miskonsepsi juga dapat bersifat menetap saat tidak terbukti salah atau mendapat tantangan konsep lain. Konsepsi yang dimiliki mahasiswa kadangkala cukup kuat dan mempunyai pengaruh yang besar terhadap pengembangan konsep-konsep tentang gaya yang didapat dari pengalaman belajarnya (Hasan, et al., 1992). Namun dalam kenyataannya konsepsi mahasiswa sering bertentangan dengan konsepsi ilmuwan, yang dapat menyebabkan kesulitan bagi mahasiswa dalam belajar.

Konsepsi mahasiswa yang berbeda dengan konsepsi ilmu pengetahuan disebut miskonsepsi (Suparno, 2005). Berbagai 
pengertian lain tentang miskonsepsi yaitu: suatu konsep yang dipercaya orang walaupun secara obyektif salah. Ide atau pemikiran yang salah; Kesalahan konsepsi, pendapat yang salah, pemahaman yang keliru (Dykstra, 1992).Nama lain dari istilah miskonsepsi yang digunakan oleh para peneliti diantaranya adalah intuisi (intuitions), konsepsi alternatif (alternative conceptions), kerangka alternatif (alternative frame), dan teori naif. Istilah-istilah tersebut digunakan untuk menghindari label salah, karena miskonsepsi mahasiswa sering merupakan bagian dari teori siswa (children theories) dalam (Gunstone, 1990; Gilbert, Osborne \& Fensham, 1992) yang tampaknya cukup logis dan cukup konsisten, meskipun tidak cocok dengan konsepsi ilmuwan. Miskonsepsi dapat diubah melalui pemberian pertanyaan, eksperimen (hukum alam selalu benar), situasi hipotetis, konflik kognitif, dan eksperimen atau demonstrasi untuk menguji hipótesis (Dykstra, et al., 1992).

$$
\text { Leinhardt, Zaslavsky,Stein }
$$

mendefinisikan miskonsepsi sebagai pemahaman yang salah dalam pengetahuan siswa yang terjadi secara berulang dan eksplisit. Miskonsepsi siswa dalam pembelajaran matematika karena kurangnya pemahaman konsep matematika.Miskonsepsi tersebut menimbulkan keprihatinan karena mengarah pada pembentukan konsep dan generalisasi yang salah sehingga menghambat pembelajaran matematika.Miskonsepsi berbeda dari kesalahan. Olivier (1989) menyatakan bahwa kesalahan adalah jawaban yang salah karena perencanaan yang tidak tepat dan tidak sistematis yang diterapkan dalam menyelesaikan permasalahan matematika, sedangkan miskonsepsi adalah gejala struktur kognitif yang menyebabkan kesalahan. Gagasan miskonsepsi merujuk pada garis pemikiran yang menyebabkan serangkaian kesalahan yang dihasilkan dari kesalahan premis yang mendasari suatu konsep atau proses tertentu, bukan kesalahan sporadis yang tidak sistematis (Nesher, 1987).

Nasser \& Carifio (1993) menyatakan bahwa selama bertahun-tahun menemukan kesalahan dalam matematika, khususnya dalam aljabar dianggap sebagai bentuk kesalahan prosedural atau komputasional.Dalam dekade terakhir ini, fokus perhatian bukan hanya pada kesalahan prosedural saja tetapi lebih ke arah kesalahan konseptual dan miskonsepsi. Penjelasan tersebut menunjukkan bahwa ternyata masalah miskonsepsi banyak mendapat perhatian dalam dunia pendidikan matematika sejak masa lampau.

Zevenbergen, Dole, Wright (2004) yang menjelaskan bahwa mengajar yang baik melibatkan pengetahuan guru tentang pemikiran siswa terkait konsep matematika dan mengetahui cara mengarahkan siswa ke arah konstruksi yang lebih kompleks, lengkap, dan kuat dengan menggunakan kegiatan, kebiasaan, dan lingkungan belajar yang terorganisir. Kesalahan konseptual dan prosedural mahasiswa sebagai calon guru 
matematika akan mengakibatkan kesalahan ketika mengajarkan kembali kepada siswanya. Penelusuran terhadap kesalahan merupakan salah satu usaha yang dapat dilakukan untuk mengatasi hal tersebut. Booth (1988) menyatakan "salah satu cara untuk mencari tahu kesulitan siswa dalam materi aljabar adalah dengan mengidentifikasi kesalahan siswa dan menyelidiki alasan dibalik terjadinya kesalahan tersebut". Oleh karena itu dilakukan penelitian untuk mengidentifikasi kesalahan dan miskonsepsi calon guru matematika pada materi SPLDV.

\section{METODE PENELITIAN}

\section{Jenis Penelitian}

Jenis penelitian ini adalah penelitian deskriptif dengan menggunakan pendekatan kualitatif. Penelitian ini mendeskripsikan jenisjenis kesulitan mahasiswa dalam menyelesaikan persoalan SPLDV.Subjek penelitian ini adalah 15 orang mahasiswa microteaching pendidikan matematika semester VI tahun ajaran 2017/2018 UNP. Mahasiswa sebagai subjek penelitian dipilih berdasarkan hasil tes tentang topik SPLDV.Mahasiswa yang terpilih adalah mahasiswa yang melakukan kesalahan terbanyak dalam menyelesaikan soal tes soal SPLDV.

\section{Waktu dan Tempat Penelitian}

Penelitian dilakukan mahasiswa microteaching pendidikan matematika semester VI tahun ajaran 2017/2018 UNP,
Padang, Sumatera Barat. Waktu pelaksanaan pada semester II Tahun Ajaran 2017/2018.

\section{Data, Intrumen, dan Teknik Pengumpulan Data}

Data dalam penelitian ini berupa data kualitatif.Data dikumpulkan melalui observasi, tes dan wawancara.Data kemampuan pemahaman konsep matematika mahasiswa diperoleh dengan memeriksa lembar jawaban tes sesuai dengan rubrik penskoran. Kemudian data tersebut dianalisis secara deskriptif kuantitatif untuk melihat pencapaian kemampuan pemahaman konsep matematika mahasiswa dalam proses perkuliahan. Rata-rata nilai akhir yang diperoleh digunakan untuk melihat kategori kemampuan pemahaman konsep matematika mahasiswa.

Wawancara dilakukan secara lisan kepada mahasiswa dengan tingkat kemampuan matematika yang berbeda.Data hasil wawancara dianalisis secara deskriptif kualitatif dan digunakan sebagai data pendukung hasil tes kemampuan pemahaman konsep matematika mahasiswa.Selain itu, wawancara juga bertujuan untuk mengetahui secara terperinci letak kesulitan mahasiswa dalam memahami konsep SPLDV.Sehingga penelitian ini menggunakan beberapa instrumen, yaitu :

a. Peneliti Sebagai Instrumen

Dalam penelitian ini, peneliti merupakan instrumen utama dalam proses pengumpulan data yang dapat memberikan interpretasi langsung terhadap realita yang ditemukan, khususnya dalam proses wawancara yang 
menuntut peran serta peneliti dalam menelusuri pemikiran mahasiswa melalui pertanyaan-pertanyaan spontan berdasarkan pola penjelasan dan jawaban siswa, sehingga diperoleh informasi yang lebih dalam terkait miskonsepsi mahasiswa.

b. Tes

Tes dalam penelitian ini merupakan tes yang dirancang untuk keperluan mendiagnosis kesulitan mahasiswa dalam menyelesaikan persoalan SPLDV. Berdasarkan hasil tes tersebut akan diidentifikasi jenis kesulitan mahasiswa.

c. Pedoman Wawancara

Pedoman wawancara dirancang untuk mempermudah peneliti dalam menggali informasi tentang mahasiswa mengenai tes diagnostik yang berkaitan dengan SPLDV.Pedoman wawancara yang digunakan berdasarkan hasil analisis dari jawaban tes SPLDV.

\section{Teknik Analisis Data}

Data yang diperoleh pada penelitian ini berupa lembar jawaban mahasiswa danhasil wawancara. Data berupa lembar jawaban mahasiswa digunakan untukmenentukan mahasiswa yang akan diwawancarai. Kelas nilai mahasiswa dikategorikan kedalam kelas rendah, sedang, dan tinggi.Mahasiswa dikelompokkan kedalam kelas nilairendah apabila nilai mahasiswa kurang dari kuartil bawah nilai mahasiswa. Mahasiswa yang nilainya lebih dari atau sama dengan kuartil bawah dan kurang dari kuartil atas dikelompokkan ke dalam kelas nilai sedang. Sedangkan mahasiswa yang nilainya lebih dari atau sama dengan kuartil atas dikelompokkan kedalam kelas nilai tinggi (Ali, 2011).

Data yang diperoleh dari hasil wawancara digunakan untuk mengidentifikasi bentuk kesalahan yang dilakukan mahasiswa dalam menyelesaikan soal cerita menurut tahapan analisis kesalahan Mahasiswa yaitu tahap membaca, pemahaman, transformasi, keterampilan proses, dan tahap pengkodean.

\section{HASIL PENELITIAN DAN PEMBAHASAN}

Pemahaman konsep merupakan kompetensi yang ditunjukkan siswa dalam memahami konsep dan dalam prosedur (algoritma) secara luwes, akurat, efisien dan tepat. Adapun indikator pemahaman konsep menurut Kurikulum 2006, yaitu:

1. menyatakan ulang sebuah konsep mengklasifikasi objek-objek menurut sifat-sifat tertentu (sesuai dengan konsepnya)

2. memberikan contoh dan non-contoh dari konsep

3. menyajikan konsep dalam berbagai bentuk representasi matematis

4. mengembangkan syarat perlu atau syarat cukup suatu konsep

5. menggunakan, memanfaatkan, dan memilih prosedur atau operasi tertentu

6. mengaplikasikan konsep atau algoritma pemecahan masalah. 
Adapun pemahaman konseptual manurut Kilpatrick, dkk; Hiebert, dkk; Ball (dalam Juandi, 2006:29), adalah pemahaman konsep-konsep matematika, operasi dan relasi dalam matematika. Beberapa indikator dari kompetensi ini antara lain: dapat mengidentifikasi dan menerapkan konsep secara algoritma, dapat membandingkan, membedakan, dan memberikan contoh dan contoh kontra dari suatu konsep, dapat mengintegrasikan konsep dan prinsip yang saling berhubungan.

Dalam NCTM 2000 disebutkan bahwa pemahaman matematik merupakan aspek yang sangat penting dalam prinsip pembelajaran matematika.Pemahaman matematik lebih bermakna jika dibangun oleh siswa sendiri.Oleh karena itu kemampuan pemahaman tidak dapat diberikan dengan paksaan, artinya konsep-konsep dan logika-logika matematika diberikan oleh guru, dan ketika siswa lupa dengan algoritma atau rumus yang diberikan, maka siswa tidak dapat menyelesaikan persoalan-persoalan matematika.

Mahasiswa dikatakan memahami konsep jika siswa mampu mendefinisikan konsep, mengidentifikasi dan memberi contoh atau bukan contoh dari konsep, mengembangkan kemampuan koneksi matematik antar berbagai ide, memahami bagaimana ide-ide matematik saling terkait satu sama lain sehingga terbangun pemahaman menyeluruh, dan menggunakan matematik dalam konteks di luar matematika. Sedangkan siswa dikatakan memahami prosedur jika mampu mengenali prosedur (sejumlah langkah-langkah dari kegiatan yang dilakukan) yang didalamnya termasuk aturan algoritma atau proses menghitung yang benar.

Berikut hasil tes kemampuan pemahaman konsep terhadap 15 orang mahasiswa calon guru matematika tentang topik SPLDV pada tabel berikut:

Tabel 1.Persentase Hasil Tes Kemampuan Pemahaman Konsep

\begin{tabular}{clcc}
\hline No & \multicolumn{1}{c}{ SPLDV } & $\begin{array}{c}\text { Benar } \\
(\%)\end{array}$ & $\begin{array}{c}\text { Salah } \\
(\%)\end{array}$ \\
\hline 1 & $\begin{array}{l}\text { SPLDV dengan solusi tak } \\
\text { hingga }\end{array}$ & 33,3 & 66,7 \\
2 & $\begin{array}{l}\text { SPLDV dengan satu } \\
\text { solusi }\end{array}$ & 33,3 & 66,7 \\
\hline
\end{tabular}

Dari tabel di atas dapat diketahui bahwa hanya sepertiga dari mahasiswa calon guru matematika yang mampu menguasai konsep SPLDV dengan baik.Selanjutnya dilakukan wawancara kepada 6 mahasiswa kelompok tinggi, sedang dan rendah.Tujuan dilakukan wawancara adalah untuk mengidentifikasi kesalah antau miskonsepsi mahasiswa terhadap konsep SPLDV.Menurut Sritarti (1994:4), kesalahan mahasiswa dalam mengerjakan soal matematika antara lain:

1. Kesalahan dalam membuat pemodelan matematika.

2. Kesalahan konsep, yaitu kesalahan dalam memahami konsep.

3. Kesalahan sistematik, yaitu kesalahan yang berkenaan dengan pemilihan yang

4. salah atas teknik ekstrapolasi. 
5. Kesalahan Strategi, yaitu kesalahan yang terjadi karena siswa memilih cara

6. mengerjakan yang tidak tepat.

7. Kesalahan tanda, yaitu kesalahan dalam memberikan atau menulis tanda atau

8. notasi matematika

9. Kesalahan hitung, yaitu kesalahan dalam melakukan operasi matematika

Hasil identifikasi kesalahan jawaban mahasiswa yang ditemukan $67 \%$ mahasiswa micro teaching menjawab dengan salah terkait dengan pemahaman konsep matematika, iantaranya: Apa Itu SPL dan SPLDV? Apa itu solusi SPLDV? Apa saja kemungkinan Solusi dalam SPLDV? Berikut contoh jawaban mahasiswa:

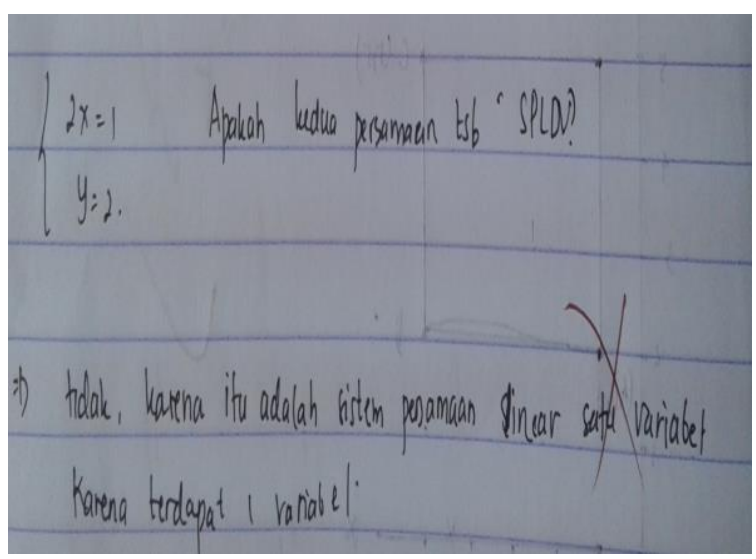

\section{Gambar 1.Jawaban Mahasiswa A (Salah)}

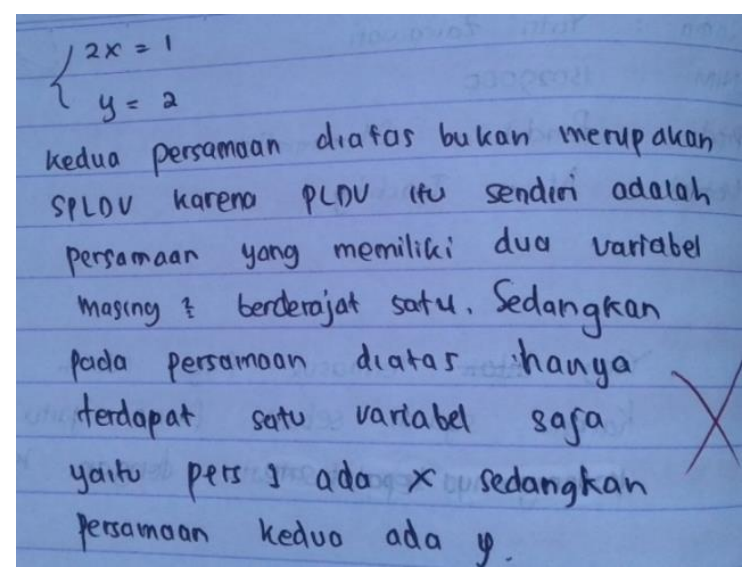

Gambar 2.Jawaban Mahasiswa B (Salah)

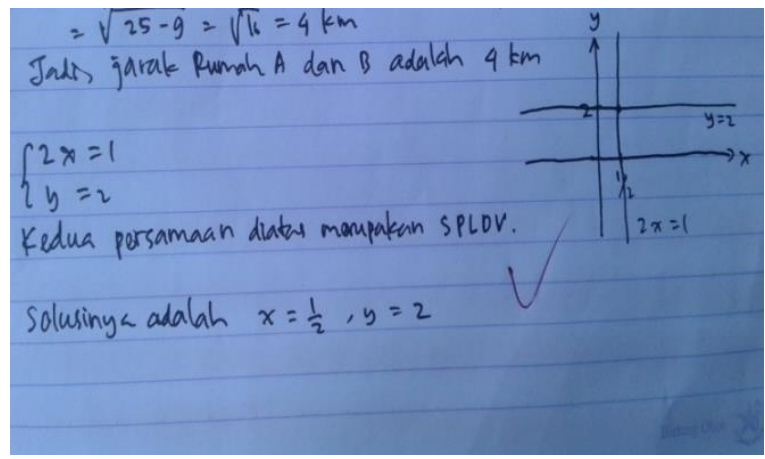

\section{Gambar 3.Jawaban Mahasiswa C (Benar)}

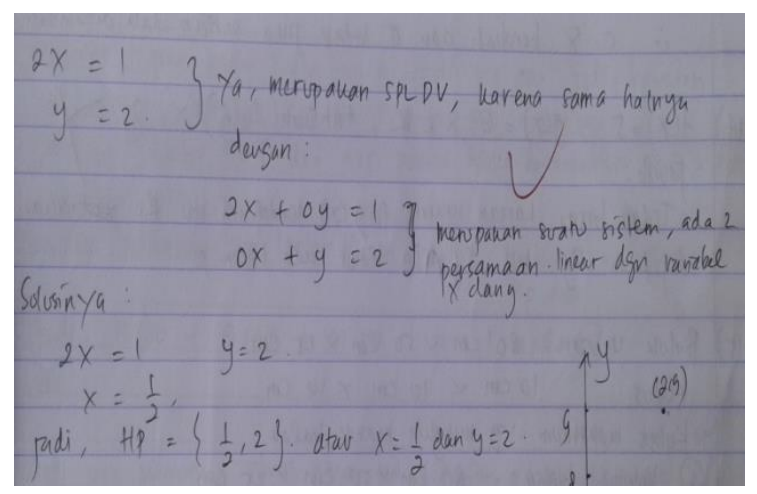

Gambar 4.Jawaban Mahasiswa D (Benar)

Berikut pertanyaan yang diajukan kepada mahasiswa yang menjawab salah: Apakah $\left.\begin{array}{r}x+2 y=3 \\ x+y=2\end{array}\right\}$ adalah SPLDV? $100 \%$ mahasiswa menjawab pertanyaan tersebut dengan benar. Selanjutnya mahasiswa ditanyai, Apa itu Solusi SPLDV dangan Metode Grafik? Jawaban Mahasiswa: Solusi SPLDV adalah titik Potong Grafik yang digambarkan. $100 \%$ mahasiswa mampu menentukan solusi dari SPL tersebut, baik dengan metode Grafik, Eliminasi, Substitusi ataupun Eliminasi-Substitusi. Secara umum jawaban mahasiswa adalah seperti gambar berikut: 


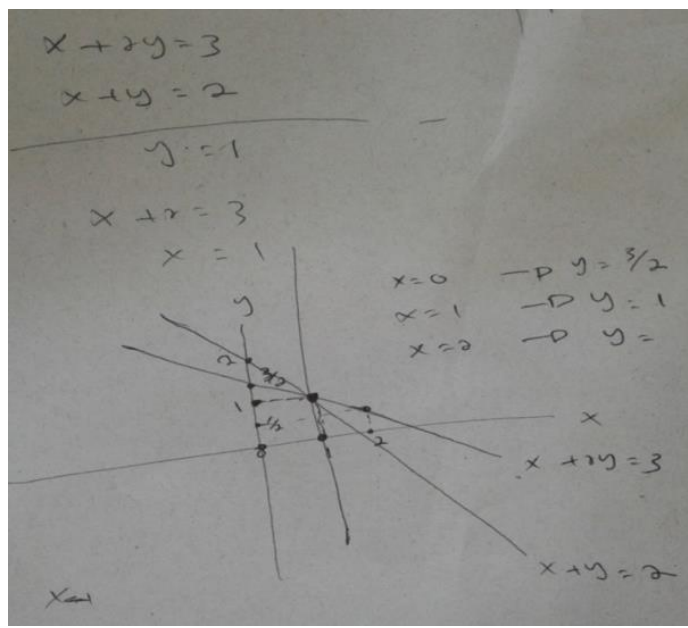

\section{Gambar 5.Jawaban Mahasiswa A}

Sehingga jika dikaitkan dengan pertanyaan SPL di awal, mahasiswa diperintahkan untuk menggambar grafik SPL yang diberikan, berikut jawaban mahasiswa:

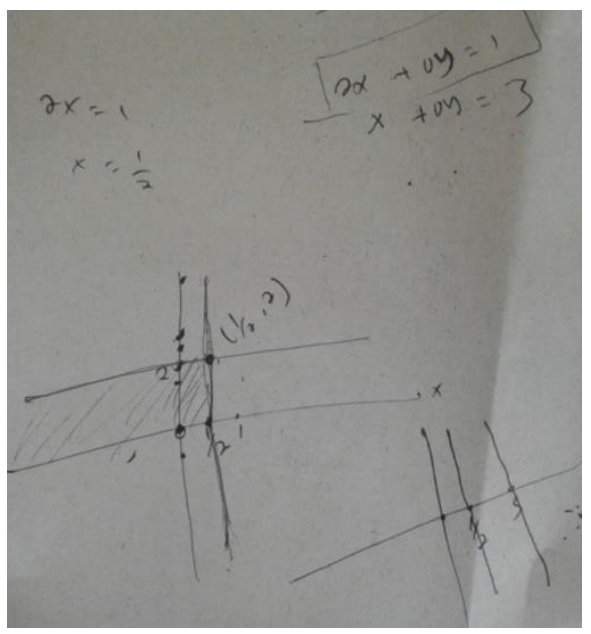

\section{Gambar 6.Jawaban Mahasiswa (Salah)}

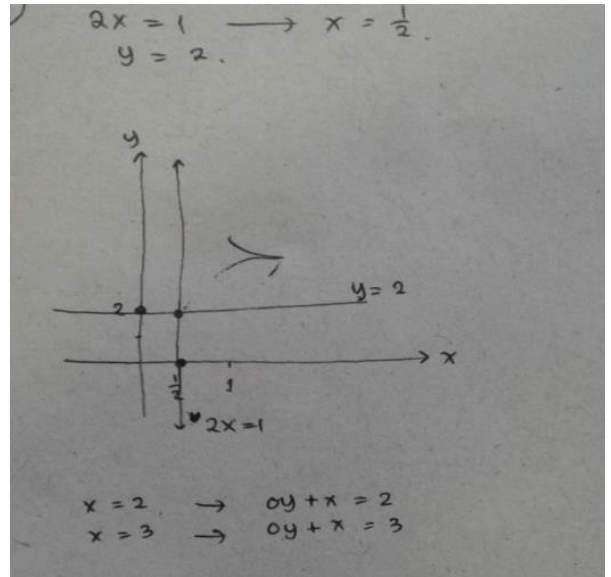

Gambar 7.Jawaban Mahasiswa (Benar)

Kesalahan lain mahasiswa terkait konsep SPLDV adalah kemungkinan solusi dari
SPLDV,Semua mahasiswa menjawab dengan benar bahwa solusi spldv (tepat satu solusi) yang ditemukan, akan berlaku untuk persamaan pertama maupun pada persamaan kedua, akan tetapi $67 \%$ mahasiswa menjawab dengan salah tentang kemungkinan solusi dari SPLDV terkait solusi SPL yang sejajar (tanpa solusi) dan berhimpit (tak hingga solusi)

Berikut juga ditemukan kesalahan mahasiswa dalam penghitungan:

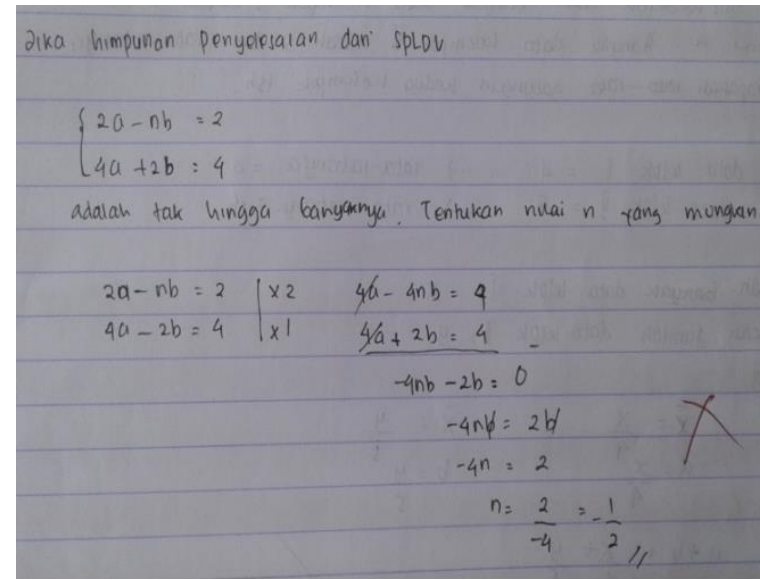

\section{Gambar 8.Jawaban mahasiswa A (salah perhitungan)}

Kesalahan tersebut tidak hanya salah dalam penghitungan, tapi saat ditanya kepada mahasiswa 80 \% dari mereka menjawab hanya secara kebetulan menentukan kemungkinan nilai $n$ dengan eliminasi.

Mahasiswa yang memahami konsep SPLDV dengan benar akan menjawab seperti berikut: 


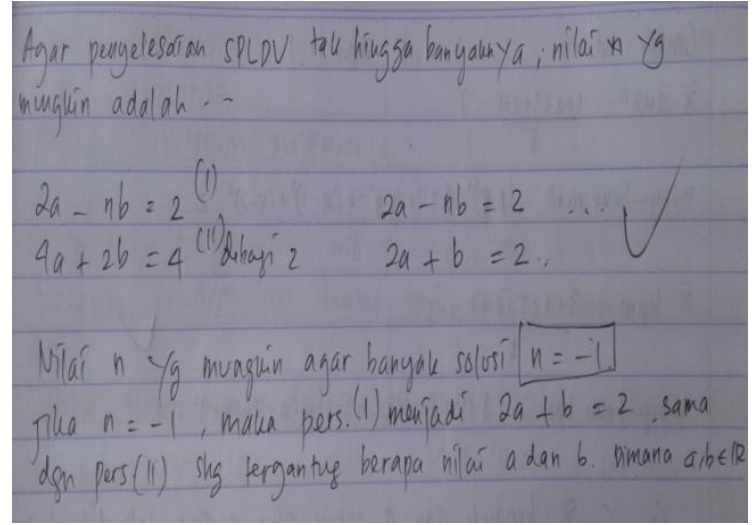

Gambar 9.Jawaban Mahasiswa D

Ketika diperintahkan untuk menggambarkan dengan grafik maka mahasiswa memperoleh kesimpulan bahwa spl berhimpit memiliki solusi tak hingga. 80 \% Mahasiswa berasumsi salah dalam mnnetukan solusi SPL yang sejajar, tetapi setelah diilustrasikan dengan grafik, muncul pemahaman baru bahwa jika dua persamaan liniear dua variabel sejajar, maka sistem persamaan tersebut tidak memiliki solusi.

Dari hasil identifikasi kesalahan subjek $A$, B, C dan D, dapat disimpulkan bahwa dalam mengerjakan soal SPLDV terdapat beberapa kesalahan yang dilakukan diantaranya adalah:
1. Kesalahan Konsep
2. Kesalahan Strategi
3. Kesalahan Hitung
4. Kesalahan Sistematik.

Kesalahan Konsep adalah kesalahan yang dilakukan mahasiswa karena tidak memahami konsep tersebut dengan baik.Aspek ini erat kaitannya dengan penguasaan materi yang dimiliki oleh mahasiswa.Dari penguasaan materi yang telah dimiliki, mahasiswa diharapkan dapat menggunakan pemahaman konsep yang dimilikinya tersebut untuk menyelesaikan persoalan yang sedang dihadapi.Kesalahan dalam memahami konsep adalah kesalahan yang dilakukan mahasiswa karena lemahnya konsep yang dikuasai.Lemahnya konsep yang dikuasai mahasiswa dapat disebabkan kurangnya partisipasi aktif ketika perkuliahan.Dalam perkuliahan sebagian mahasiswa hanya mendapatkan informasi dan mengerjakan soal latihan yang diberikan oleh dosen. Oleh karena itu, untuk pemahaman konsep yang lebih baik maka mahasiswa harus berpartisipasi aktif dalam perkuliahan dan dosen harus memberikan tugas berupa permasalahan dan soal mengenai konsep geometri analitik.

Kesalahan Strategi adalah kesalahan yang terjadi karena mahasiswa memilih cara mengerjakan yang tidak tepat. Kesalahan ini terjadi disebabkan oleh pemahaman konsep mahasiswa yang lemah.Ketika mengerjakan suatu soal mahasiswa kebingungan dalam menentukan langkah selanjutnya yang harus ditempuh, meskipun mahasiswa tersebut mengetahui konsep atau rumus yang digunakan. Untuk meminimalisir kesalahan tersebut mahasiswa dapat memperbanyak latihan soal sehingga pemahaman akan konsep tersebut dapat dikuasai.

Kesalahan hitung adalah kesalahan dalam melakukan operasi matematika.Kesalahan hitung ini disebabkan karena ketidaktelitian mahasiswa dalam mengerjakan soal meskipun mahasiswa sudah menguasai mengenai konsep yang diberikan.Kesalahan Sistematik adalah 
kesalahan yang berkenaan denganpemilihan yang salah atas teknik ekstrapolasi.Kesalahan sistematik yang dilakukan dalam penelitian ini adalah kesalahan dalam menggunakan rumus.

Dari tes soalditemukanbahwa mahasiswa mengalami miskonsepsiyang beragam tingkatan, yaitu tingkat tinggi,sedang dan rendah. Miskonsepsi yang dialamisetiap mahasiswa dapat berlainan dengan penyebabyang berbeda-beda.Pada bebarapamahasiswa dapatterjadi bermacammacam miskonsepsi denganpenyebab miskonsepsi berbeda pula.Oleh karena itu, sangat penting bagi dosen untuk mengenalimiskonsepsi dan penyebabnya yang terjadi padamahasiswa.

Menurut filosofi konstruktivisme, pengetahuan mahasiswa dikontruksi atau dibangun oleh mahasiswa sendiri. Proses konstruksi tersebut diperoleh melalui interaksi dengan benda, kejadian dan lingkungan. Pada saat mahasiswa berinteraksi dengan lingkungan belajarnya, mahasiswa mengkonstruksi pengetahuan berdasarkan pengalamannya. Oleh karena itu, ketika proses kontruksi pengetahuan terjadi pada mahasiswa, sangat besar kemungkinan terjadinya kesalahan dalam proses mengkontruksi karena secara alami mahasiswa belum terbiasa mengkontruksi pe ngetahuan sendiri secara tepat. Apalagi jika tidak didampingi sumber informasi yang jelas dan akurat.
Konstruksi pengetahuan mahasiswa tidak hanya dilakukan sendiri tetapi juga dibantu oleh konteks dan lingkungan mahasiswa, diantaranya teman-teman di sekitar mahasiswa, buku teks, guru dan lainnya.Jika aspek-aspek tersebut memberikan informasi dan pengalaman yang berbeda dengan pengertian ilmiah maka sangat besar kemungkinan terjadinya miskonsepsi pada mahasiswa tersebut.Oleh karena itu, aspek-aspek tersebut merupakan penyebab terjadinya miskonsepsi pada mahasiswa.Aspek-aspek yang dapat menyebabkan terjadinya miskonsepsi adalah mahasiswa itu sendiri, guru, dan metode pembelajaran yang digunakan dosen di kelas. Dengan menggunakan wawancara secara intensif peneliti memperoleh data penyebab miskonsepsi yang dialami oleh mahasiswa yaitu ada yang karena ketidak tahuan, kesalahan bahasa, tayangan film, kemampuan berfikir, latar belakang keluarga, konsepsi parallel, dan kesalahan konsepsi awal mahasiswa.

\section{SIMPULAN DAN SARAN}

\section{Simpulan}

Dari penelitian ini maka dapat diidentifikasi beberapa kesalahan dan miskonsepsi yang dilakukan mahasiswa dalam mengerjakan soal SPLDV diantaranya adalah sebagai berikut: 1) Kesalahan konsep, yaitu kesalahan yang yang dilakukan mahasiswa karena tidak memahami konsep SPLDV dengan dengan baik. 2) Kesalahan strategi, yaitu kesalahan yang terjadi karena mahasiswa 
memilih caramengerjakan yang tidak tepat. 3) Kesalahan hitung, yaitu kesalahan dalam melakukan operasi matematika. 4) Kesalahan Sistematik, yaitu kesalahan yang berkenaan dengan pemilihan yang salahatas teknik ekstrapolasi.

Dengan menggunakan wawancara secara intensif peneliti memperoleh data penyebab miskonsepsi yang dialami oleh mahasiswa yaitu ada yang karena ketidak tahuan, kesalahan bahasa, tayangan film, kemampuan berfikir, latar belakang keluarga, konsepsi parallel, dan kesalahan konsepsi awal mahasiswa.

\section{Saran}

Untuk meminimalisir kesalahan yang dilakukan dalam mengerjakan soal soal SPLDV maka mahasiswa harus berperanaktif dalam kegiatan perkuliahan, serta memperbanyak latihan soal sehingga akanmeningkatkan pemahaman konsep mengenai SPLDV.

\section{REFERENSI}

Ali, Muhammad F. 2011. Analisis kesalahan penyelesaian soal cerita matematikaberbahasa Inggris melalui tahapan analisis kesalahan Newman pada siswa RSBI SMP Laboratorium UM , Skripsi tidak diterbitkan. Malang : FMIPA Universitas Negeri Malang

Booth, L.R. (1988). Children's difficulties in beginning algebra. In Coxford A.F. and Shulte A.P. (Eds.) The Ideas of Algebra, K12. Reston, VA: NCTM.
Dykstra, et al. (1992)."Studying Coceptual Change in Learning Physics".Journal Research in Science- Teaching, 74 (5)

Depdiknas. 2003. Pedoman Khusus Pengembangan Sistem Penilaian Berbasis Kompetensi SMP. Jakarta: Depdiknas.

Duffin, J.M.\& Simpson, A.P. 2000. A Search for understanding.Journal of Mathematical Behavior. 18(4): 415-427.

Gilbert, J.K. Osborne, R.J and Fensham, P.J. (1992). "Children's Science dan it's Consequences for Teaching". Journal of Science Education, 65 (4): 623-633.

Gunstone, R.F. (1990). “Children's Science A Decade of Development in Constructivist View of Science Teaching and Learning". ASTJ, Vol. 36, No. 4.

Hasan, S. Bagayoko, D. and Kelly, E. L. (1992). Misconception and The Certainty of Response Index". Journal of Physics Education, 30.Suparno, P. (2005).Miskonsepsi dan Perubahan Konsep Pendidikan Fisika.Jakarta: Gramedia.

Juandi, D. 2006. Meningkatkan Daya Matematik Mahasiswa Calon Guru Matematika Melalui Pembelajaran Berbasis masalah.Disertasi Pascasarjana UPI Bandung: tidak diterbitkan.

Kesumawati, N. (2008). Pemahaman Konsep Matematik dalam Pembelajaran Matematika.

(http://eprints.uny.ac.id/6928/1/P18\%20Pe ndidikan\%28Nila\%20K\%29.pdf).

Leinhardt, G., Zaslavsky, O., \&Stein, M.K. (1990).Functions, graphs, and graphing.Review of Educational Research, 6o(1), 1-64.

Mulyono, A. (1999). Pendidikan Bagi Anak Berkesulitan Belajar. Jakarta: PT. Rieneka Cipta. 
Nasser, R.,\& Carifio, J. (1993). Students misconceptions and errors in solving algebra word problems related to misconceptions in the field of science. Proceedings of the Third International Seminar on Misconceptions and Educational Strategies in Science and Mathematics, Misconceptions Trust.Ithaca, August 1-4 1993.

National Council of Teachers of Mathematics (2000).Principles and Standars for School Mathematics. Reston, VA: NCTM.

Nesher, P. (1987). Towards an intructional theory: the role of student's misconceptions. For the Learning of Mathematics, 7(3), 33-39.

Olivier, A. (1989). Handling pupils' misconceptions.Mathematics Education for Pre-Service and In-Service, 1(1), 193-209.
Skemp, R.R. (1976). Relational understanding and instrumental understanding.(http://www.alearningplac e.com.au/wpcontent/uploads/2014/01/atta chments/pdf/Skemp\%2opaper.pdf).

Suherman, E. 2003.Strategi Pembelajaran Matematika Kontemporer. Bandung: Jurusan Pendidikan Matematika FPMIPA UPI.

Sumarmo, U. 1987. Kemampuan Pemahaman dan Penalaran Matematik Siswa SMA Dikaitkan dengan Penalaran Logik Siswa dan Beberapa Unsur Proses Belajar Mengajar. Disertasi pada Pascasarjana IKIP Bandung: tidak diterbitkan

Van de Walle, J., A. 2008. Matematika Sekolah Dasar dan Menengah.Jakarta : Erlangga.

Zevenbergen, R., Dole, S., \& Wright, R. J. (2004). Teaching mathematics in primary schools. Australia: Allen \& Unwin. 